\title{
UJI PERFORMANSI PENGARUH VARIASI HEAD VORTEX TERHADAP PRESTASI TURBIN VORTEX
}

\author{
Dedy A. Girsang ${ }^{1}$, Syahril Gultom ${ }^{2}$, Andianto P. ${ }^{3}$, Mahadi ${ }^{4}$, Pramio G. Sembiring ${ }^{5}$ \\ 1.2,3,4,5 Departemen Teknik Mesin, Fakultas Teknik, Universitas Sumatera Utara \\ E-mail : armand_thetrozz@yahoo.co.id
}

\begin{abstract}
ABSTRAK
Pembangkit listrik tenaga air saat ini menjadi salah satu pilihan dalam memanfaatkan sumber energi terbarukan. Namun pemanfaatan yang ada masih menggunakan teknologi yang sedehana. Salah satu contoh dalam bidang teknik mesin terutama dalam bidang konversi energi dan pemanfaatan alam sebagai sumber energi. Diantaranya adalah pemanfaatan air yang bisa digunakan untuk menghasilkan tenaga listrik. Seorang Peneliti dari Jerman Viktor Schauberger mengembangkan teknologi aliran vortex (pusaran) untuk diterapkan pada pemodelan turbin air. Tujuan dari penelitian ini adalah untuk mengetahui pengaruh luas saluran buang, luas sudu dan ketinggian head. Adapun manfaat dari penelitian ini adalah mengidentifikasi karakteristik aliran vortex di dalam vortex basin dan potensi pemanfaatannya pada aliran sungai untuk menghasilkan daya listrik.Dari penelitian ini didapatkan efisiensi sebesar $75 \%$ dengan tinggi air jatuh 0,6 m.Turbin pusaran air (vortex) ini dioperasikan pada daerah yang memiliki head yang rendah. Aliran air yang digunakan berasal dari bak penampungan di alirkan melalui saluran air (talang) kapasitas aliran (debit) air yang digunakan dapat diatur melalui sebuah katup pengatur (gate valve) sesuai kebutuhan. Aliran air yang mengalir melalui talang memiliki energi kinetik sehingga akan membentuk pusaran yang akan menggerakkan sudu turbin vortex sebagai energi input.Efisiensi daya turbin tertinggi pada ketinggian $7 \mathrm{~cm}$ pada A1 sebesar $63,412 \%$. Sementara itu daya poros tertinggi berada pada ketinggian 35 pada A1 sebesar 6,45574 watt..
\end{abstract}

Kata kunci: Vortex, Debit, Diameter Basin

\section{PENDAHULUAN}

Dalam kemajuan teknologi sekarang ini banyak dibuat peralatan- peralatan yang inovatif dan tepat guna. Salah satu contoh dalam bidang teknik mesin terutama dalam bidang konversi energi dan pemanfaatan alam sebagai sumber energi. Diantaranya adalah pemanfaatan air yang bisa digunakan untuk menghasilkan tenaga listrik. Listrik, sebuah kata yang hampir tidak bisa dihilangkan dalam kehidupan masyarakat saat ini. Hampir semua aktivitas manusia zaman sekarang membutuhkan listrik.

Pembangkit listrik tenaga air saat ini menjadi salah satu pilihan dalam memanfaatkan sumber energi terbarukan. Namun pemanfaatan yang ada masih menggunakan teknologi yang sedehana. Pembangkit Listrik jenis ini dalam proses pembuatannya sangat ekonomis namun masih dalam skala kecil. Artinya pembangkit-pembangkit ini hanya mampu mencukupi pemakaian energi listrik untuk sejumlah rumah saja. Jenis Pembangkit Listrik Tenaga Air ini sering disebut Microhydro atau sering juga disebut Picohydro tergantung keluaran daya listrik yang dihasilkan [1].

Seorang Peneliti dari Jerman Viktor Schauberger mengembangkan teknologi aliran vortex (pusaran) untuk diterapkan pada pemodelan turbin air. Aliran vortex yang juga dikenal sebagai aliran pulsating atau pusaran dapat terjadi pada suatu fluida yang mengalir dalam suatu saluran yang mengalami perubahan mendadak. Fenomena aliran vortex sering kali dijumpai pada pemodelan sayap pesawat, aliran vortex cenderung dianggap sebagai suatu kerugian dalam suatu aliran fluida.. 


\section{TINJAUAN PUSTAKA Vorteks}

Vorteks adalah sebuah komponen utama dalam aliran Turbulen[1]. Dengan tidak adanya gaya luar, gesekan viskos dalam cairan cenderung membuat aliran menjadi kumpulan yang disebut vortisitas irrotasional. Dalam pusaran tersebut, kecepatan fluida yang terbesar berada di samping sumbu imajiner, dan penurunan kecepatan berbanding terbalik terhadap jarak dari sumbu imajner. Pusaran sangat tinggi di wilayah inti sekitar sumbu, dan hampir nol di ujung pusaran; sementara tekanan turun tajam saat mendekati wilayah itu. Setelah terbentuk, vorteks dapat berpindah, meregang, berputar, dan berinteraksi secara kompleks.

\section{Vorteks Paksa / Vorteks Berotasi}

Vorteks Paksa dikenal juga sebagai vorteks flywheel. Jika fluida berputar seperti benda kaku - yaitu, jika $v$ naik secara proporsional terhadap r - bola kecil yang dibawa oleh arus juga akan berputar pada pusatnya seolah-olah itu adalah bagian dari benda kaku. Dalam hal ini, vektor omega adalah sama di mana-mana. Arahnya sejajar dengan sumbu putar, dan besarnya adalah dua kali kecepatan sudut untuk seluruh fluida. Aplikasi dari turbin ini dapat dilihat pada gambar 2.1 berikut.

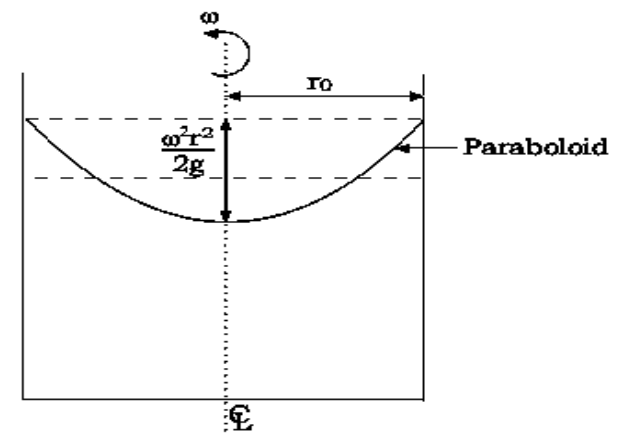

Gambar 2.1 Teh Cangkir yang di aduk adalah sebuah Aplikasi Vorteks paksa [2]

\section{Vorteks Bebas / Vorteks Tak Berotasi}

Ketika massa fluida bergerak secara alami (karena pengaruh gaya-gaya internal) dalam sebuah kurva aliran, gerakan vorteks bebas akan muncul, dalam kasus ini tidak ada torsi ataupun gaya eksternal yang mempengaruhi fluida. Vorteks bebas dikenal juga sebagai potential vorteks. Jika kecepatan tangensial partikel Ut berbanding terbalik dengan jarak r, maka percobaan bola khayalan tidak akan berputar terhadap dirinya sendiri; ini akan mempertahankan arah yang sama sambil bergerak dalam lingkaran di sekitar garis vorteks dan aliran dikatakan tak berotasi. Contoh dari gerakan vorteks bebas adalah aliran air yang keluar dari lubang yang berada di dasar tangki, aliran di pipa yang melengkung, aliran di pinggiran rumah keong pompa, tepat setelah keluar dari impeller pompa sentrifugal, dan aliran angin siklon [2]

\section{Turbin Air}

Turbin air dikembangkan pada abad 19 dan digunakan secara luas untuk industry pembangkit listrik [3]. Sekarang lebih umum dipakai untuk generator listrik. Turbin kini dimanfaatkan secara luas dan merupakan sumber energi yang dapat diperbaharukan. Kincir air sudah sejak lama digunakan untuk industri tenaga listrik. Pada mulanya yang 
dipertimbangkan adalah ukuran kincirnya, yang membatasi debit dan head yang dapat dimanfaatkan. Perkembangan kincir air menjadi turbin modern membutuhkan jangka waktu yang cukup lama. Perkembangan yang dilakukan dalam waktu revolusi industry menggunakan metode dan prinsip ilmiah. Mereka juga mengembangkan teknologi material dan metode produksi baru pada saat itu.

\section{Klasifikasi Turbin Air}

Turbin hidrolik adalah suatu alat yang dapat menghasilkan torsi sebagai akibat gaya dinamik dan gaya tekan air, turbin hidrolik ini dapat dikelompokkan menjadi dua tipe, yaitu :

1. Turbin Reaksi (reaction turbine) adalah turbin yang mengkombinasikan energypotensial tekan dan energi kinetik untuk menghasilkan energi gerak.

2. Turbin Impuls (impuls turbine) adalah turbin yang memanfaatkan energikinetik dari pancaran air yang berkecepatan tinggi untuk diubah menjadienergi gerak.

Diagram klasifikasi turbin air dapat dilihat pada gambar 2.2 dibawah ini.

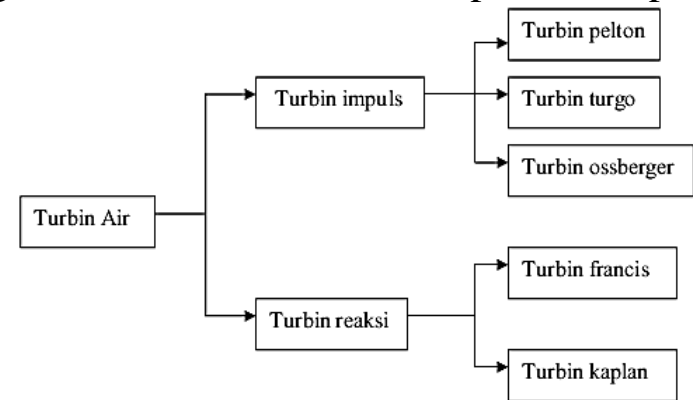

Gambar 2.2 Klasifikasi Turbin air [4]

\section{Turbin Vorteks}

Turbin ini dinamakan sebagai Gravitation Water Vorteks Power Plant (GWVPP) oleh penemunya Frans Zotleterer berkebangsaan Austria, tetapi nama turbin ini dikenal juga sebagai turbin Vorteks atau turbin pusaran air [5]. Sesuai dengan namanya pusaran air, air ini memanfaatkan pusaran air buatan untuk memutar sudu turbin dan kemudian energi pusaran air diubah menjadi energi putaran pada poros. Prosesnya air dari sungai dialirkan melalui saluran masuk ke tanki turbin yang berbentuk lingkaran dan di bagian tengah dasar tanki terdapat saluran buang berupa lingkaran kecil. Akibat saluran buang ini maka air mengalir akan membentuk aliran pusaran air. Ketinggian air (head) yang diperlukan untuk turbin ini 0,7 - $2 \mathrm{~m}$ dan debit berkisar 1000 liter per detik. Turbin ini sederhana, mudah dalam perawatannya, kecil, kuat, dan bertahan hingga 50 - 100 tahun. Gambar dari turbin vorteks dapat dilihat pada gambar 2.3 berikut.

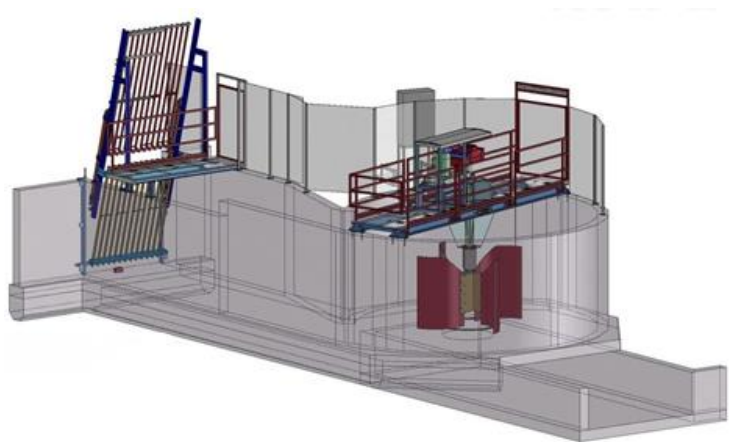

Gambar 2.3 Turbin vorteks 


\section{METODOLOGI PENELITIAN}

\section{Umum}

Turbin pusaran air (vortex) merupakan salah satu turbin yang sangat spesial, karena dapat beroperasi pada daerah yang memiliki head yang sangat rendah. Turbin pusaran air (vortex) bekerja pada head rendah. Sebagai simulasi atau pengkondisian dari air mengalir yang berada di alam. Dalam uji eksperimental turbin vortex ini, dibuat turbin vortex, adapun beberapa pekerjaan yang dilakukan adalah:

* Pembuatan sudu dari besi plat

* Pembuatan poros

* Pembuatan rumah turbin (casing)dari bahan kaca akrilik (acrylic)

* Pembuatan bak penampungan air (reservoir)

* Pembuatan saluran air dari bak penampungan (talang)

* Pembuatan saluran buang (output)

Dan ditambah beberapa instalasi turbin vortex.Adapun penambahan instalasi yang dilakukan adalah:

> Instalasi saluaran air masuk (talang) dengan bak penampungan air reserfoir.

$>$ Instalasi dudukan bak penampungan

$>$ Instalasi dudukan pengujian turbin vortex

$>$ Instalasi saluran buangan air pada turbin vortex

\section{PENGUJIAN TURBIN VORTEX}

Turbin Vortex yang digunakan dalam uji eksperimental turbin vortex menggunakan jumlah runner sebanyak 4 buah dengan diameter $(15,5 \mathrm{~cm})$

Lubang buang yang digunakan dalam pengujian berikut adalah dengan dameter $10,5 \mathrm{~cm}$, yang disesuaikan dengan ketersediaan diameter pipa komersial yang tersedia di pasar.

Head / ketinggian air yang divariasikan pada pengujian kali ini ada 5, yaitu:

- $\mathrm{H} 1=7 \mathrm{~cm}$

- $\mathrm{H} 2=14 \mathrm{~cm}$

- $\mathrm{H} 3=21 \mathrm{~cm}$

- $\mathrm{H} 4=28 \mathrm{~cm}$

- $\mathrm{H} 5=35 \mathrm{~cm}$

Seluruh variasi ketinggian head air di basin diukur dari dasar vortex basin.

\section{INSTALASI TURBIN VORTEX}

Diameter dalam turbin (casing) adalah $0.5 \mathrm{~m}$, dengan tinggi rumah turbin $(\mathrm{h})=0,4 \mathrm{~m}$. Rancang bangun instalasi uji eksperimental turbi vortex terdapat pada lantai empat (rooftop) Teknik Mesin USU.

Adapun elemen yang meliputi perancangan turbin vortex adalah :

\section{Rumah turbin ( Vortex Basin )}

Rumah turbin berbentuk lingkaran terbuat dari acrylic dengan diameter 0,5 meter dengan tinggi 0,4 meter 
Poros turbin

Poros yang digunakan terbuat dari pipa besi

Bak penampungan air (reservoir)

Sudu turbin

Sudu turbin terbuat dari plat datar $2 \mathrm{~mm}$ yang dilengkungkan denga menggunakan roller

Bantalan (bearing)

bantalan yang digunakan adalah P204 dengan jumlah 2 buah .

Dudukan turbin

Dudukan turbin terbuat dari besi siku yang sudah dilas

Saluran buang

Saluran buang terbuat dari baja dan diletakkan di bagian tengah dasar rumah turbin.

\section{PERALATAN PENGUJIAN}

1. Pulley

Pulley digunakan untuk mengukur besarnya momen puntir yang dihasilkan oleh putaran sudu melalui poros dengan cara dihubungkan ketimbangan pegas menggunakan tali. Dalam uji eksperimental turbin vortex pada debit1, debit2 dan debit 3, pulley yang digunakan memiliki spesifikasi diameter $18 \mathrm{~cm}$

2. Hand TachometerAlat ini digunakan untuk mengukur putaran (rpm) poros turbin vortex. Dalam uji eksperimental turbin vortex pada debit1, debit2 dan debit 3, hand tachometer yang digunakan adalah Krisbow KW06-303 dengan spesifikasi:

Ketelitian (akurasi) $: \pm 0,05 \%+1$ digit Range

autorange

Sampling time : 0,8 s (over $60 \mathrm{rpm}$ )

3. Timbangan Pegas

Timbangan Pegas digunakan untuk mengukur besarnya momen puntir (kilogram) yang dihasilkan melalui pulley pada poros dengan cara melingkarkan tali pada pulley kemudian diikatkan ke timbangan pegas. Dalam uji eksperimental turbin vortex pada debit1, debit2 dan debit 3, timbangan pegas yang digunakan adalah dengan spesifikasi 5 $\mathrm{kg}$

4. Pompa Pengumpan

Pompa ini digunakan untuk mengumpankan air dari tempat penampungan bawah ke reserfoar . pompa pengumpan yang digunakan adalah pompa sentrifugal 2 (dua) inchi dengan daya motor penggerak $(\mathrm{P}) 0,75 \mathrm{~kW}$.

5. Multimeter

Multimeter digunakan untuk mengukur tegangan (voltmeter).

6. Instalasi Rangkaian Lampu 
Pada instalasi ini mengunakan rangkaian paralrel yang terdiri dari lampu LED 4 dan 3 watt masing-masing sebanyak 1 buah. Pada masing-masing lampu dipasang sakelar yang berfungsi untuk menghubungkan dan memutuskan aliran listrik ke lampu

7. Generator

Generator listrik adalah sebuah alat yang memproduksi energi listrik dari sumber energi mekanik berdasarkan prinsip induksi elektromagnetik

8. Water pass

Water pass digunakan untuk memeriksa kedataran dan ketegakan dari semua bagian Turbin Vortex

9. Sabuk (belt)

Sabuk digunakan untuk mentransmisikan tenaga dari poros turbin ke generator melalui puli.

10. Clamp Meter

Clamp Meter digunakan untuk mengukur besarnya arus listrik (ampere) yang yang dihasilkan melalui rangkaian listrik (beban) dengan cara dihubungkan seri pada rangkaian listrik

11. Gelas Ukur

Gelas ukur digunakan untuk mengetahui debit air masuk melalui reservoir ke basin maupun air kelur basin $(\mathrm{Q} 1=\mathrm{Q} 2)$. Dalam uji eksperimental turbin vortex pada debit $\mathrm{H} 1$, debit $\mathrm{H} 2$, debit $\mathrm{H} 3$, debit $\mathrm{H} 4$

\section{PELAKSANAAN PENGUJIAN}

Uji eksperimental turbin vortex dilakukan dengan menggunakan instalasi turbin vortex yang dilakukan di rooftop lantai empat, Departemen Teknik Mesin, Fakultas Teknik Universitas Sumatera Utara. Pengukuran-pengukuran yang dilakukan tehadap penelitian ini meliputi:

1. Pengukuran putaran (rpm) poros turbin vortex dengan menggunakan Hand Tachometer.

2. Pengukuran momen puntir (kilogramforce) dengan menggunakan Timbangan Pegas.

3. Pengukuran arus listrik (ampere) dan tegangan (volt) menggunakan clamp meter danmultimeter

4. Pengukuran debit air dengan menggunakan stopwatch dan gelas ukur.

Sebelum dilakukan pengujian turbin vortex dan pengambilan data, terlebih dahulu dilakukan pemeriksaan (checking) terhadap beberapa instalasi dan peralatan, yang meliputi:

1. Pemeriksaan volume air di dalam tempat penampungan bawah.

2. Pemeriksaan pipa penghubung antara pompa pengumpan dan bak penampungan

3. Pemeriksaan reservoir

4. Pemeriksaan poros turbin vortex serta pemperian pelumas pada bearing.

5. Pemeriksaan belt dan pulley.

6. Pemeriksaan pompa-pompa pengumpan.

7. Pemeriksaan instalasi alternator dan lampu 
Setelah prosedur pemeriksaan terhadap beberapa instalasi dan peralatan di atas selesai dilakukan dan pemeriksaan dipastikan dalam kondisi standby, maka prosedur pengujian pun dapat dimulai. Adapun prosedur pengujian uji eksperimental turbin vortex dengan sudu B1 adalah sebagai berikut:

1. Pengujian pertama dilakukan dengan pemasangan lubang buang dan sudu B1.

2. Hidupkan pompa pengumpan .

3. Dilakukan monitoring terhadap ketinggian air di dalam reservoir dan penampungan bawah turbin .

4. Setelah ketinggian air di bak penampungan reservoir mencukupi, maka dilakukan pengujian serta pengambilan data terhadap:
a) Pengukuran putaran (rpm) pada poros Turbin vortex dengan menggunakan Hand Tachometer
b) Pengukuran momen puntir (kilogram) dengan menggunakan Timbangan Pegas.
c) Pengukuran arus listrik (ampere) dan tegangan (volt) menggunakan Multimeter.

5. Pengukuran terhadap beberapa variabel dilakukan terhadap ketinggian air $7(\mathrm{~cm}), 14(\mathrm{~cm})$, $21(\mathrm{~cm}), 28(\mathrm{~cm}), 35(\mathrm{~cm})$.

6. Setiap pengambilan data dilakukan sebanyak sepuluh kali untuk mendapatkan data pengujian yang lebih akurat dan spesifik.

Besaran-besaran yang diukur dan dicatat meliputi:

- $\quad$ Debit air masuk $(\mathrm{Q})$

- Putaran poros Turbin Vortex (rpm)

- Momen Puntir Turbin Vortex (kilogramforce Nm)

- Arus listrik (ampere) dan tegangan (volt) yang dihasilkan Turbin Vortex.

Dari besaran-besaran di atas dapat dihitung besaran turunan lainnya seperti:

1. Daya Air

2. Daya Turbin Vortex

3. Daya Listrik keluaran Alternator

4. Efisiensi Turbin Vortex

Setelah pengujian di atas, dilakukan pengujian debit air dengan prosedur sebagai berikut:

1. Katup menuju talang pada turbin dibuka.

2. Pompa pengumpan dihidupkan dan air dipompakan dari tempat penampungan bawah ke reserfoar.

3. Secara bersamaan stopwatch dihidupkan.

4. Segera setelah stopwatch dihidupkan selama beberapa detik, pompa pengumpan dan stopwatch dimatikan. Pencatatan data dilakukan, meliputi waktu $t$ (detik) dan volume air dalam ember penampungan $\left(\mathrm{m}^{3}\right)$.

Dari data yang diperoleh, maka perhitungan debit air pun dapat dilakukan dengan cara volume air yang ditampung di wadah penampung diukur dengan gelas pengukur (L) dan dibagi waktu $(t)$ yang diperoleh.

\section{HASIL PENGUJIAN}

Pengujian Debit

Pada pengujian ini data dikumpulkan dari pengujian aliran tanpa sudu, dengan perkiraan debit keluaran maksimum dari aliran paling stabil. Jumlah percobaan setiap variasi dulakukan 10 kali percobaan. Datanya dapat dilihat pada Tabel 4.1. 
Tabel 4.1 Debit

\begin{tabular}{|c|c|}
\hline Debit $(\mathbf{m} / \mathbf{s})$ & $\begin{array}{c}\text { Ketinggian Air } \\
(\mathbf{c m})\end{array}$ \\
\hline 0,82068 & 7 \\
\hline 1,64136 & 14 \\
\hline 2,46204 & 21 \\
\hline 3,28272 & 28 \\
\hline 4,1034 & 35 \\
\hline
\end{tabular}

Pengujian RPM Maksimum

Data pengujian merupakan nilai rata-rata yang di ambil dari sampel 10 kali perngujian,dengan waktu 10 detik.Data didapat dengan pembacaan alat hand tachometer pada poros turrbin vortex.Hasil pengujian dapat dilihat pada Tabel 4.2 dan Gambar 4.1.

Tabel 4.2 Hasil pengujian

\begin{tabular}{|c|c|c|}
\hline \multicolumn{3}{|c|}{$\begin{array}{c}\text { DATA PENGUJIAN PUTARAN } \\
\text { MAKSIMUM (RPM) }\end{array}$} \\
\hline $\begin{array}{c}\text { Ketinggian } \\
\text { Air (cm) }\end{array}$ & Runner A1 & Runner A 2 \\
\hline 7 & 41,68803822 & 16,60981959 \\
\hline 14 & 124,3839783 & 50,7525707 \\
\hline 21 & 130,0700255 & 102,1236865 \\
\hline 28 & 148,2947799 & 155,1638838 \\
\hline 35 & 226,1568296 & 205,1243931 \\
\hline
\end{tabular}

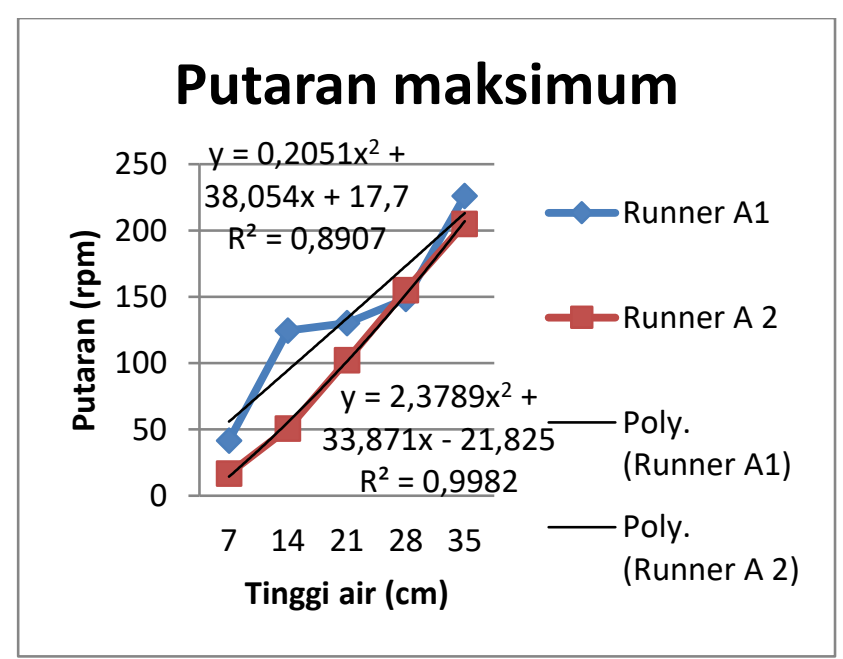

Gambar 4.1 Grafik putaran tanpa beban

Pengujian Torsi-Putaran Berbeban

Data pengujian didapat dari pengukuran yang dilakukan dalam waktu yang bersamaan (sekaligus).Dalam kasus ini,pengujian membutuhkan waktu yang cukup lama untuk menentukan pembebanan yang tepat sebelum poros berhenti berputar.Pembebanan ini dilakukan menggunakan gesekan tali yang dikaitkan pada 2 neraca pegas.waktu pengujian sampel sepanjang 20 detik,dibutuhkan lebih dari $15 \mathrm{x}$ pengujian (sampel) untuk setiap 
perubahan variasi.Pengukuran putaran dilakukan dalam kondisi poros terbeban hampir berhenti Hasil pengujian dapat dilihat pada Tabel 4.3.

Tabel 4.3 Hasil pengujian putaran berbeban

\begin{tabular}{|c|c|c|}
\hline \multicolumn{3}{|c|}{$\begin{array}{c}\text { DATA PENGUJIAN TORSI } \\
\text { BERBEBAN (Nm) }\end{array}$} \\
\hline $\begin{array}{c}\text { Ketinggian Air } \\
(\mathrm{cm})\end{array}$ & Runner A1 & Runner A 2 \\
\hline 7 & 0,9 & 2 \\
\hline 14 & 1 & 2 \\
\hline 21 & 2 & 2 \\
\hline 28 & 3 & 2,2 \\
\hline 35 & 3 & 2,5 \\
\hline
\end{tabular}

\section{Lubang Buang 4}

Pengujian dilakukan dengan menggunakan alternator dan rangkaian listrik tertutup berbeban. Beban berupa lampu, besar beban terpasang maksimum 7 watt.Datanya dapat dilihat pada Tabel 4.4.

Tabel 4.4 Pengujian arus

\begin{tabular}{|c|c|c|}
\hline \multicolumn{3}{|c|}{ DATA PENGUJIAN ARUS (milli } \\
ampere) \\
\hline $\begin{array}{c}\text { Ketinggian } \\
\text { air }\end{array}$ & Runner A1 & Runner A 2 \\
\hline 7 & 0 & 0 \\
\hline 14 & 0 & 0 \\
\hline 21 & 0,03712908 & 0 \\
\hline 28 & 0,063497129 & 0,04872146 \\
\hline 35 & 0,058101746 & 0,043915268 \\
\hline
\end{tabular}

Tabel 4.5 Pengujian tegangan

\begin{tabular}{|c|c|c|}
\hline \multicolumn{3}{|c|}{ DATA PENGUJAN TEGANGAN (volt) } \\
\hline Ketinggian air & Runner A1 & Runner A 2 \\
\hline 7 & 0 & 0 \\
\hline 14 & 0 & 0 \\
\hline 21 & 30 & 0 \\
\hline 28 & 30 & 30 \\
\hline 35 & 50 & 50 \\
\hline
\end{tabular}

Analisa Perhitungan Daya-Efisiensi

Dari konsep daya hidrolik air, maka akan didapat potensi energi yang dapat dipanen dari sejumlah air dengan kondisi ketinggian tertentu, dengan rumusan;

$$
\begin{aligned}
\mathrm{P}_{\text {air }}= & \rho \times \mathrm{g} \times \mathrm{Q} \times \mathrm{H} \\
& \text { Atau } \\
\mathrm{P}_{\text {air }}= & \rho \times \mathrm{W} \times \mathrm{H}
\end{aligned}
$$


Untuk menghitung daya turbin, digunakan persamaan:

$$
\mathrm{P}_{\text {turbin }}=\Gamma(\mathrm{Nm}) \times \mathrm{n}(\mathrm{rad} / \mathrm{s})
$$

Untuk menghitung efisiensi turbin, digunakan persamaan:

$$
\eta(\%)=\frac{P_{\text {turbin }}}{P_{\text {air }}} \times 100 \%
$$

Hasil perhitungan dapat dilihat pada Tabel 4.5 dan Gambar 4.2.

Tabel 4.6 Efisiensi Daya Turbin Berbeban

\begin{tabular}{|c|c|c|}
\hline \multicolumn{3}{|c|}{ HASIL PERHITUNGAN } \\
EFISIENSI DAYA TURBIN \\
BERBEBAN (\%) \\
\hline $\begin{array}{c}\text { Ketinggian } \\
\text { Air }\end{array}$ & Runner A1 & $\begin{array}{c}\text { Runner } \\
\text { A2 }\end{array}$ \\
\hline 7 & 63,412 & 56,145 \\
\hline 14 & 52,556 & 42,889 \\
\hline 21 & 48,852 & 38,356 \\
\hline 28 & 46,994 & 36,059 \\
\hline 35 & 45,868 & 34,669 \\
\hline
\end{tabular}

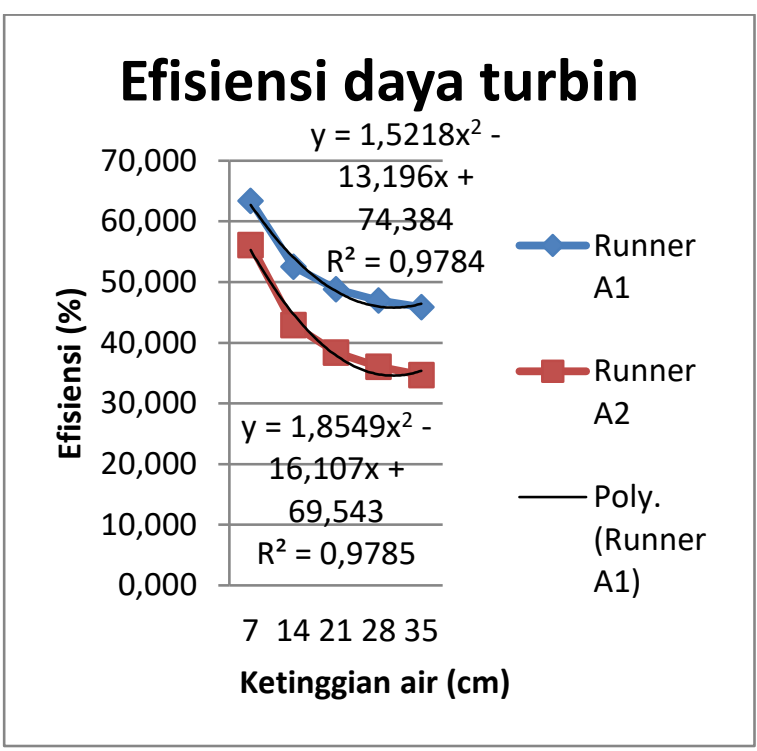

Gambar 4.2 Efisiensi Daya Turbin Berbeban

\section{KESIMPULAN}

Dari uji performansi pengaruh variasi head vortex terhadap prestasi turbin vortex (dengan spesifikasi : tinggi 40 dan lebar $50 \mathrm{~cm}$ menggunakan $2 \mathrm{sudu}$ ) didapat beberapa kesimpulan:

1. Diperoleh tingkat efisiensi daya turbin terdapat pada tiap ketinggian pada runner A1:

$$
\begin{array}{ll}
7 \mathrm{~cm} & : 63,412 \% \\
14 \mathrm{~cm} & : 52,556 \% \\
21 \mathrm{~cm} & : 48,52 \% \\
28 \mathrm{~cm} & : 46,994 \% \\
35 \mathrm{~cm} & : 45,868 \%
\end{array}
$$

2. Diperoleh tingkat efisiensi daya turbin terdapat pada tiap ketinggian pada runner A2:

$7 \mathrm{~cm} \quad: 56,145 \%$ 


$$
\begin{aligned}
& 14 \mathrm{~cm}: 42,889 \% \\
& 21 \mathrm{~cm}: 38,356 \% \\
& 28 \mathrm{~cm}: 36,059 \% \\
& 35 \mathrm{~cm}: 34,669 \%
\end{aligned}
$$

\section{Saran}

1. Untuk uji performansi pengaruh variasi head vortex terhadap prestasi turbin vortex berikutnya diharapkan melakukan penelitian terhadap jumlah sudu yang lebih akurat.misalnya dengan membandingkan data yang dihasilkan dengan menggunakan 8 sudu sampai 10 sudu.

2. Untuk uji performansi pengaruh variasi head vortex terhadap prestasi turbin vortex berikutnya diharapkan menggunakan variasi lubang buang lebih dari 2 jenis.

3. Untuk uji performansi pengaruh variasi head vortex terhadap prestasi turbin vortex berikutnya disarankan menggunakan diameter basin 5 meter untuk pengaplikasian aktual pada sungai.

\section{DAFTAR PUSTAKA}

[1] L. V. Steeter dan Wylie B. 1993. Mekanika Fluida. Edisi Kedelapan. Jakarta: Erlangga.

[2] Khurmi, R.E. 1984. A Text Book Of Hydraulic Machine. Ram Nagar, Newdelhi: S. Chand and Company LTD.

[3] Fritz Dietzel, Dakso Sriyono. Turbin Pompa dan Kompressor. Erlangga. Jakarta. 1990.

[4] http:// water turbine-wikipedia, the free envyclopedia.html

[5] M.M. Dandekar, K.N. Sharma. Pembangkit Listrik Tenaga Air. UI. Press Jakarta. 1991. 